\title{
SQUAMOUS CELL CARCINOMA OF THE ESOPHAGUS AND MULTIPLE PRIMARY TUMORS OF THE UPPER AERODIGESTIVE TRACT
}

\author{
Ulysses RIBEIRO Jr., Ivan CECCONELLO, Adriana Vaz SAFATLE-RIBEIRO, \\ Bruno ZILBERSTEIN and Henrique Walter PINOTTI
}

\begin{abstract}
Squamous cell carcinoma of the esophagus is frequently associated with other, synchronous or metachronous tumors, in the upper aerodigestive tract. All 264 patients with squamous cell carcinoma of the esophagus, treated in the Gastrointestinal Surgery, Esophagus section, of the "Hospital das Clinicas" (São Paulo University Medical School, Brazil), between 1979 and 1989 were analyzed retrospectively with regards to the occurrence of multiple primary tumors in the upper aerodigestive tract. Multiple primary tumors were encountered in 10 (3.8\%) patients. All patients were male and the mean age at the time of the first primary was 52.2 years. Tobacco smoke and alcohol were the principal carcinogens in these patients $(n=10)$. The sites of the tumors were: larynx $(n=4)$, tongue $(n=4)$, lung $(n=2)$, and oral cavity $(n=1)$. Two simultaneous, three synchronous and five metachronous multiple primary carcinomas were detected. The esophagus was the second primary tumor in nine patients. The mean overall survival after the diagnosis of the second primary was 2.8 months $(S D=0.89)$. Inquiry regarding other malignancies, associated with panendoscopy should be carry out prior to the treatment of the first primary to diagnose simultaneous or synchronous primary tumors, and careful follow-up should be performed after treatment of the first primary to detect new tumors in these high-risk patients.
\end{abstract}

HEADINGS - Esophageal neoplasms. Carcinoma, squamous cell. Neoplasms, multiple primary. Respiratory system.

Department of Gastroenterology, São Paulo University Medical School, São Paulo, SP, Brazil.

Address for correspondence: Dr. Ulysses Ribeiro, Jr. - Rua Treze de maio, 1954, Cj. 54 - 01327-002 - São Paulo, SP, Brazil. e-mail: ulysses@dialdata.com.br. 


\section{INTRODUCTION}

Patients with tumors of the upper aerodigestive tract are at increased risk for development of second primary cancers at the same region. Viral infections, nutritional deficiencies and dietary customs have been postulated to play a role in the carcinogenesis process, rendering the mucosa susceptible to development of multiple tumors ${ }^{(3,18,27)}$. In this context, tobacco smoke and alcohol are the foremost carcinogens in the upper aerodigestive $\operatorname{tract}^{(3,18,27)}$. SLAUGHTER ${ }^{(23)}$, in 1946, was the first to postulate the concept of multicentric and independent origin of carcinomas. Since then, several reports of multiple primary tumors have appeared in the literature. Because of longer life span, earlier diagnosis and improved methods for treatment of such tumors, multiple primary tumors have been found more often ${ }^{(14,21)}$.

Two theories have been described to explain the appearance of multiple carcinomas. The monoclonal neoplasia theory presume that progeny from a single transformed cell may spread to produce multiple tumors, while the field effect model predicts that independent tumors develop from the genotoxic effects of carcinogens ${ }^{(3,}$ 23). The entire mucosa of the upper aerodigestive tract, when exposed to such local irritants as tobacco smoke and alcohol, is at risk for developing cancer ${ }^{(12)}$. According to the theory of field carcinogenesis, areas of atypical epithelial hyperplasia, metaplasia, pre-invasive carcinoma (in situ), and fully developed carcinoma may be found at various sites in the upper aerodigestive $\operatorname{tract}^{(14)}$.

Investigation of multiple primary tumors may be relevant, since the stage of the patient, treatment, follow-up, surveillance and prognosis may be altered by the presence of a second primary. In the present study, we retrospectively analyzed the presence of multiple tumors of the upper aerodigestive tract in patients treated for squamous cell carcinoma of the esophagus.

\section{PATIENTS AND METHODS}

We reviewed 264 patients with primary squamous cell carcinoma of the esophagus treated at the Esophagus Section of the Gastrointestinal Surgery of the "Hospital das Clínicas" of the University of São Paulo Medical School between 1979 and 1989. Tumors were retrospectively staged from the pathologic reports according to the Committee of the International Union Against Cancer (TNM). Multiple tumors were defined according to the criteria of WARREN and GATES $^{(26)}$. Each tumor had to be clearly malignant histologically, each had to be geographically distinct, and the possibility that one tumor represented a metastasis had to be excluded. Differentiation between metastasis and a second primary carcinoma was aided by evaluation of the clinical course of the first primary tumor and the histologic characteristics of the tumors. Tumors were regarded as simultaneous when both primary cancers were diagnosed at the same time, synchronous when the second primary tumor was diagnosed within six months of the first and metachronous when the diagnosis of the second primary tumor took place at least six months after the diagnosis of the index tumor ${ }^{(24,25)}$. We considered upper aerodigestive tract to be oral cavity, larynx, pharynx, esophagus, and tracheobronchial tree.

\section{RESULTS}

Ten patients $(3.8 \%)$ had multiple primary tumors of 264 patients with primary squamous cell carcinoma of the esophagus. One patient interestingly developed three tumors (larynx, tongue and esophagus). The principal clinical characteristics are presented in Table 1. The mean age at the time of the first primary tumor was 52.2 years
$(\mathrm{SD}=+10.8)$. All patients were male with an increased exposition to tobacco (greater than 40 cigarettes/day/25 years) and to alcohol (greater than $90 \mathrm{~g}$ ethanol/day). The predominant race was white in nine cases. The mean interval between the first primary and the second was 3.5 years $(\mathrm{SD}=5.2$ years; $95 \%$ Confidence Interval $=0.2-7.26)$. The first primary tumors were all located at the upper aerodigestive tract and consisted of: larynx $(\mathrm{n}=4)$; tongue $(\mathrm{n}=3)$; lung $(\mathrm{n}=1)$; oral cavity $(\mathrm{n}=1)$ and esophagus $(\mathrm{n}=1)$ (Table 1). The esophageal tumor was the second primary in nine patients. Two patients had simultaneous tumors, three presented with synchronous and five patients had metachronous tumors. The TNM stage is presented in Table 1. The first primary tumors were treated with a combination of surgery and radiotherapy in four patients, surgical resection in one and radiotherapy in five patients. Second primary tumors were treated by surgical resection in three patients, palliative measures in four, and radiotherapy in two, all of which were located at the esophagus. One esophageal cancer patient presented a second primary in the lung and had no treatment. Two patients were lost of follow-up and another died from surgical complications (pneumonia). All other patients died from disease and the mean overall survival was 2.8 months $(\mathrm{SD}=0.89$ months; $95 \%$ Confidence Interval $=1.9$ - 3.6).

\section{DISCUSSION}

In this study, $3.8 \%$ of all patients treated for esophageal carcinoma presented multiple primary tumors of the upper aerodigestive tract. The reported incidence of esophageal carcinoma associated with multiple primary squamous cell carcinomas of the upper aerodigestive tract in series of head and neck tumor patients varies from $0 \%$ to $6.3 \%^{(1,2,3 \text {, }}$ 4, 5, 7, 8, 9, 10,11, 12, 13, 14, 17, 18, 19, 22, 25) (Table 2). Furthermore, the incidence of multiple primary tumors in series of patients with 


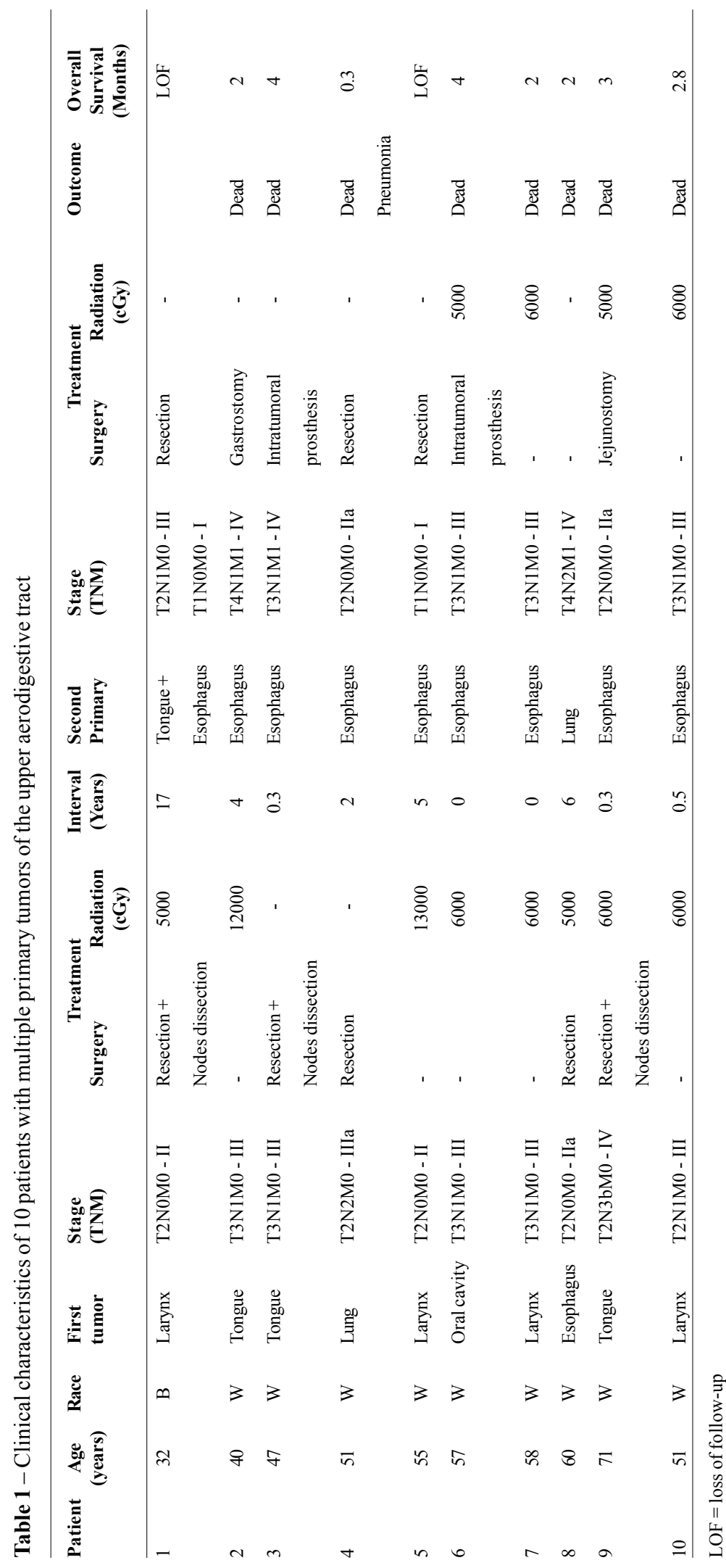

squamous cell carcinoma of the esophagus ranged from $3.3 \%$ to $12.4 \%{ }^{(2,4,9,20,21,24)}$ (Table 3). This wide range in incidence can be partially explained by the site of the initial tumor, type of treatment, ethnic or racial differences, increasing awareness of such tumors, more accurate evaluation and improved survival rates following treatment of the initial primary ${ }^{(1,3,11,20,25)}$.

Our data showed that all patients were heavy smokers and alcohol abusers. The risk may be directly proportional to the amount and duration of exposure to carcinogens. $\operatorname{MOORE}^{(15)}$ found that $40 \%$ of patients with index cancers of the oral cavity, pharynx and larynx, who continued to smoke developed a second primary, while only $6 \%$ who stopped smoking after onset of the first lesion did so. The risk of developing a second primary cancer is also enhanced significantly by more intensive, combined exposures to tobacco and alcohol prior to the index cancer ${ }^{(5,18,27)}$. When comparing former cigarette with current cigarette smokers, prospective studies have generally indicated a $25-50 \%$ reduction in risk of cancer of the oral cavity and larynx by smoking cessation $^{(5,18,27)}$.

These multiple neoplasms are highly selective on a site-specific basis presumably due to common etiologic factors associated with the initial cancer. The field effect theory has been advanced to explain these so-called synchronous and metachronous carcinomas $^{(23)}$. Study of patients with multiple primary tumors of the upper aerodigestive tract for the presence and specific genotype of p53 gene mutations showed a complete discordance in p53 genotype between separate primary tumors of the same patient. Different mutations in tumors from the same patient indicate that these tumors are independents and therefore favor the field effect theory ${ }^{(16)}$.

Radiation therapy for one cancer may act as a predisposing factor for the occurrence of 
Table 2 - Reported series of patients with squamous cell carcinoma of the head \& neck region and multiple primary tumors of the upper aerodigestive tract

\begin{tabular}{|c|c|c|c|c|c|c|}
\hline Authors / Year & $\begin{array}{l}\text { Number of } \\
\text { patients }\end{array}$ & $\begin{array}{l}\text { Type of } \\
\text { study }\end{array}$ & $\begin{array}{c}\text { Follow up } \\
\text { (years) }\end{array}$ & $\begin{array}{c}\text { Head \& neck } \\
\text { tumors (\%) }\end{array}$ & $\begin{array}{c}\text { Other } \\
\text { locations (\%) }\end{array}$ & $\begin{array}{c}\text { Esophagus } \\
(\%)\end{array}$ \\
\hline \multirow[t]{2}{*}{ Schottenfeld et al. ${ }^{(18)}-1974$} & 733 & Prospective & 5 & $18.2 / 1000$ men & 9.8 & 1 \\
\hline & & & & $15.4 / 1000$ women & 8.4 & \\
\hline Golsdtein and Zornoza $^{(8)}-1978$ & 10 & Retrospective & 30 & & & 1 \\
\hline Cahan et al. ${ }^{(4)}-1976$ & 7 & Retrospective & & & & 0.6 \\
\hline Shapshay et al. ${ }^{(19)}-1980$ & 150 & Retrospective & & & & 6 \\
\hline Gluckman et al. $.^{(7)}-1980$ & 577 & Retrospective & 6 & 2.4 & & 0 \\
\hline Maisel and Vermeersch ${ }^{(13)}-1981$ & 449 & Endoscopy & - & 8.01 & & 1.1 \\
\hline \multirow[t]{2}{*}{ Miyahara et al. ${ }^{(14)}-1985$} & 1.389 & Retrospective & 23 & 9.94 & & 1.2 \\
\hline & Larynx & & & & & \\
\hline Leipzig et al. ${ }^{(12)}-1985$ & 384 & Endoscopy & 1.2 & 8.9 & 3.6 & 1.8 \\
\hline Shons and McQuarrie ${ }^{(22)}-1985$ & 405 & Retrospective & 15 & 13 & & 4.2 \\
\hline \multirow[t]{2}{*}{ de Vries and Snow ${ }^{(25)}-1986$} & 748 & Retrospective & & 14 & & 0 \\
\hline & Larynx & & & & & \\
\hline Abemayor et al. ${ }^{(1)}-1988$ & 150 & Endoscopy & & & & 2 \\
\hline Robinson et al. ${ }^{(17)}-1992$ & 1.294 & Retrospective & 9 & 12.6 & & 1.6 \\
\hline \multirow[t]{2}{*}{ Hiyama et al. ${ }^{(10)}-1992$} & 472 & Prospective & 8.6 & 24.3 & & \\
\hline & Larynx & & & & & \\
\hline Boysen and Loven ${ }^{(3)}-1993$ & 714 & Prospective & 5 & 11.7 & & 1.4 \\
\hline \multirow[t]{2}{*}{ Ina et al. ${ }^{(11)} 1994$} & 127 & Endoscopy + & & & & 6.3 \\
\hline & & Lugol & & & & \\
\hline Day et al..$^{(5)} 1994$ & 1090 & Case-control & 5 & 8.7 & & \\
\hline Atabek et al. ${ }^{(2)}-1990$ & 1982 & Retrospective & 24 & & & 2.5 \\
\hline Shibuya et al. ${ }^{(21)}-1995$ & 3.375 & Retrospective & 34 & 13 & 1.3 & 2.4 \\
\hline
\end{tabular}

Table 3 - Reported series of patients with esophageal carcinoma and multiple primary tumors of the upper aerodigestive tract

\begin{tabular}{lccc}
\hline Authors / Year & $\begin{array}{c}\text { Number of } \\
\text { patients }\end{array}$ & $\begin{array}{c}\text { Multiple } \\
\text { primaries (\%) }\end{array}$ & $\begin{array}{c}\text { UAT } \\
(\%)\end{array}$ \\
\hline Goodner and Watson $^{(9)}-1956$ & 1315 & 9.5 & 4 \\
Cahan et al. ${ }^{(4)}-1976$ & 1000 & & 6 \\
Shibuya et al. ${ }^{(20)}-1982$ & 339 & 8.3 & 3.3 \\
Atabek et al. ${ }^{(2)}-1990$ & 394 & & 7.1 \\
Shibuya et al. ${ }^{(21)}-1995$ & 434 & & 12.4 \\
Voormolen et al. ${ }^{(24)}-1995$ & 242 & 8.7 & 5 \\
Fiks et al. $^{(6)}-1996$ & 152 & 4.6 & 7.2 \\
\hline
\end{tabular}

UAT $=$ upper aerodigestive tract another cancer. We had four patients who develop second primary tumors in the irradiated field, but we could not deduce that these tumors were related to the radiotherapy.

The role of endoscopy is not completely well established. Some studies support the routine panendoscopic evaluation for all patients who present with squamous cell carcinoma of the upper aerodigestive tract ${ }^{(2,}$ $3,5,12,13,17)$, while others showed that endoscopic screening may not be worthwhile ${ }^{(24)}$. 
In the present study, $50 \%$ of the tumors presented as simultaneous or synchronous malignancies. The majority $(n=8 / 10)$ of the patients who developed a subsequent primary carcinoma survived less than three months from its diagnosis, and died from these tumors. Therefore, attention should be given to the patient's complaints and adequate investigation pursued prior to the treatment in order to detect multiple primaries as soon as possible. The most important consequence of early diagnosis of multiple primary tumors would probably be that their detection might influence the treatment of the index tumor and the outcome. Indications for surgery should be determined by the extent of the two tumors. Only radical surgery with extirpation of both tumors may lead to relatively favorable results.

Because of the clear risk for multiple primary tumors, we agree with others and recommend that all patients with tumors of the upper aerodigestive tract should undergo close medical follow-up over a long period of time to enable the early detection of second

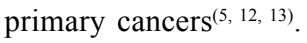

Inquiry regarding other malignancies, associated with panendoscopy should be carry out prior to the treatment of the first primary to diagnose simultaneous or synchronous primary tumors, and careful follow-up should be performed after treatment of the first primary to detect new tumors in these high-risk patients.

Ribeiro Jr U, Cecconello I, Safatle-Ribeiro AV, Zilberstein B, Pinotti HW. Carcinoma epidermoide do esôfago e múltiplos tumores primários do trato aerodigestivo alto. Arq Gastroenterol, São Paulo, 36(4):195-200, 1999.

RESUMO - Carcinoma epidermóide do esôfago está freqüentemente associado a outros, sincrônicos ou metacrônicos tumores do trato aerodigestivo alto. Foram analisados, retrospectivamente, 264 pacientes com carcinoma de esôfago tratados na Disciplina de Cirurgia do Aparelho Digestivo, Divisão de Cirurgia do Esôfago, do Hospital das Clínicas da Faculdade de Medicina da Universidade de São Paulo, entre 1979 e 1989, com o intuito de se observar a ocorrência de múltiplos tumores primários do trato aerodigestivo alto. Observaram-se $10(3.8 \%)$ pacientes com múltiplos tumores primários. Todos eram do sexo masculino e a média de idade ao tempo do primeiro tumor foi 52.2 anos. Os locais dos tumores primários foram: laringe $(n=4)$, língua $(n=3)$, pulmão $(n=2)$, cavidade oral $(n=1)$ e esôfago $(n=$ 1). Dois tumores eram simultâneos, três sincrônicos e cinco metacrônicos. O esôfago foi o segundo tumor primário em nove pacientes. A sobrevida média depois do diagnóstico do segundo tumor primário foi de apenas 2.8 meses $(D P=0.89)$. Na tentativa de se diagnosticar outros tumores, o exame clínico associado com panendoscopia deve ser realizado antes de se tratar o tumor inicial, a fim de que se possa diagnosticar tumores simultâneos ou sincrônicos. Ademais, deve ser realizado cuidadoso seguimento após o tratamento do primeiro tumor pois estes pacientes apresentam risco de aparecimento de novos tumores.

DESCRITORES - Neoplasias esofágicas. Carcinoma de células escamosas. Neoplasias primárias múltiplas. Sistema respiratório.

\section{REFERENCES}

1. Abemayor E, Moore DM, Hanson DG. Identification of synchronous esophageal tumors in patients with head and neck cancer. J Surg Oncol, 38:94, 1988.

2. Atabek U, Mohit-Tabatabai MA, Rush BF, Ohanian M, Rovelli P. Impact of esophageal screening in patients with head and neck cancer. Am Surg, 56:289, 1990.

3. Boysen M, Loven JO. Second malignant neoplasms in patients with head and neck squamous cell carcinomas. Acta Oncol, 32:283, 1993.
4. Cahan WG, Castro EB, Rosen PP, Strong EW. Separate primary carcinomas of the esophagus and head and neck region in the same patient. Cancer, 37:85, 1976.

5. Day GL, Blot WJ, Shore RE, McLaughlin JK, Austin DF, Greenberg RS, Liff JM, Preston-Martin S, Sarkar S, Schoenberg JB, Fraumeni, Jr JF. Second cancers following oral and pharyngeal cancers: role of tobacco and alcohol. J Natl Cancer Inst, 86:131, 1994.

6. Fiks IN, Pedreira WL, Carvalho CRR, Zilberstein B, Cecconello I. Associated tumors of the upper aerodigestive tract: the role of staging and endoscopic follow-up in early detection. ABCD Arq Bras Cir Dig, 11:58, 1996. 
7. Gluckman JL, Grissman JD, Donegan JO. Multicentric SCC of the upper aerodigestive tract. Head Neck Surg, 3:90, 1980.

8. Goldstein HM, Zornoza J. Association of squamous cell carcinoma of the head and neck with cancer of the esophagus. Am $\mathbf{J}$ Roentgenol, 131:791, 1978.

9. Goodner JT, Watson WL. Cancer of the esophagus: its association with other primary cancers. Cancer, 9:1248, 1956.

10. Hiyama T, Sato T, Yoshino K, Tsukuma H, Hanai A, Fujimoto I. Second primary cancer following laryngeal cancer with special reference to smoking habits. Jpn J Cancer Res, 83:334, 1992.

11. Ina H, Shibuya H, Ohashi I, Kitagawa $M$. The frequency of a concomitant early oesophageal cancer in male patients with oral and oropharyngeal cancer. Screening results using lugol dye endoscopy. Cancer, 73:2038, 1994.

12. Leipzig B, Zellmer JE, Klug D, The Panendoscopy Study Group. The role of endoscopy in evaluating patients with head and neck cancer. A multi-institutional prospective study. Arch Otolaryngol, 111:589, 1985.

13. Maisel RH, Vermeersch H. Panendoscopy for second primaries in head and neck cancer. Ann Otol, 90:460, 1981.

14. Miyahara H, Yoshino K, Umatani K, Sato T. Multiple primary tumours in laryngeal cancer. J Laryngol Otol, 99:999, 1985.

15. Moore C. Cigarette smoking and cancer of the mouth, pharynx, and larynx. A continuing study. JAMA, 218:553, 1971.

16. Ribeiro Jr U, Safatle-Ribeiro AV, Posner MC, Rosendale B, Bakker A, Swalsky PA, Kim R, Reynolds JC, Finkelstein SD. Comparative p53 mutational analysis of multiple primary cancers of the upper aerodigestive tract. Surgery, 120:45, 1996.

17. Robinson E, Zauber A, Fuks Z, Strong E. Clinical characteristics of patients with epidermoid carcinoma of the upper aerodigestive tract who develop second malignant tumors. Cancer Detection \& Prevention, 16:297, 1992.

18. Schottenfeld D, Gantt RC, Wynder EL. The role of alcohol and tobacco in multiple primary cancers of the upper digestive system, larynx and lung: a prospective study. Prev Medicine, 3:277, 1974.

19. Shapshay SM, Hong WK, Fried MP, Sismaris A, Vaughan SW, Strong MS. Simultaneous carcinomas of the oesophagus and upper aerodigestive tract. Otolaryngol Head Neck Surg, 88:373, 1980.

20. Shibuya H, Takagi M, Horiuchi J, Suzuki S, Kamiyama R. Carcinomas of the esophagus with synchronous or metachronous primary carcinoma in other organs. Acta Radiol Oncol, 21:39, 1982.

21. Shibuya H, Wakita T, Nakagawa T, Fukuda H, Yasumoto M. The relation between an oesophageal cancer and associated cancers in adjacent organs. Cancer, 76:101, 1995.

22. Shons AR, McQuarrie DG. Multiple primary epidermoid carcinomas of the upper aerodigestive tract. Arch Surg, 120:1007, 1985.

23. Slaughter DA. Multicentric origin of intraoral carcinoma. Surgery, 20:133, 1946

24. Voormolen MHJ, van Deelen RAJ, Tilanus HW, van Lanchot JJB. Esophageal carcinoma and multiple primary tumors. Dis Esophagus, 8:218, 1995.

25. Vries ND, Snow GB. Multiple primary tumours in laryngeal cancer. J Laryngol Otol, 100:915, 1986.

26. Warren S, Gates DC. Multiple primary malignant tumors: a survey of the literature and statistical study. Am J Cancer, 16:1358, 1932.

27. Wynder EL, Mushinski MH, Spivak JC. Tobacco and alcohol consumption in relation to the development of multiple primary cancers. Cancer, 40:1872, 1977. 